notice on my part because it impugns not only the verbal statements made to many astronomers who have inspected the instruments of the U.S. Naval Observatory, but also the correctness of an official report made by me to the Superin. tendent of the Naval Observatory, and appended by him to his report for the year $1 \mathrm{~S}_{93}$, printed $\mathrm{c}$ 'pies of which hive been distributed to nearly all the observaiories in the world.

The paragraph in question is based upon an illustrated article in the Zeitschrift fiir Inslrumentenkunde, 1894, 14 Jahrgang. pp. 12S-130, which purports to be a description of the 12 -inch equatorial telescope of the Georgetown College Observatory, and in which it is asserted ( 1 ) that the instrument was constructed nearly thrie y'car's ago by Mr. Gco. N. Saegmuller, of Washington, 1).C. ; (2) that its principal novelty is a pair of star dials, or finding circles; and (3) that similar instruments have been constructed by Mr. Saegmuller for the U.S. Naval Observatory at Vashington, and for other institutions which are named. From these statements the writer of the "Astronomical Column" very naturally inferred that Mr. Saegmuller constructed these dials, or finding circles, three years ago, when in reality he did nothing of the kind. The facts are as follows:The idea of these finding circles first occurred to me while the question of building a 12 .inch equatorial mounting for the U.S. Naval Observatory was under consideration, and in the specif. cations for that instrument, which were dated May 20, ISgr, I embodied it in these words: "Connected with them (the quick motions) and arranged so as always to face a person operating them, suitable indicators shall be provi.led for showing auto. matically the right ascension and declination of the point to which the telescope is directed." Mr. Saegmuller got the contract for buildin that mounting, and the details of these indicators were arranged between us. The erection of the mounting at the Naval Observatory was comple:ed in November 1892, and almost immediately thereafier Mr. Saegmuller put an exact copy of its indicators upon the Georgetown College telescope, which he had crected some time previously. Finally, the two woodcuts which illustrate the Zeilsihrifi's article are not pictures of the Georgetown College telescope, but of the Naval Observatory telescope, which differs from the Georgetown instrument in many details.

Washington, D.C., June 7 .

\section{On the Use of Quartz Fibres in Telescopes.}

Perilats it may interest some of your readers to know that the quariz fibres of Prof. Boys affords an excellent material for providing the eye-lens of telescopes, and specially the instruments used in combination with reflesting galvanometers and electrometers, with threads required for their adjustment on the divisions of the scale. I thought at first that as the fibres appear, when examined with the microscope, to be semi-transparent and have a silver.grey colour, they would, when seen behind the ocular lene, not present themselv $s$ as distinct and clear lines, but as a matter of fact, when they were put at the proper distance, they showed an intense blatk colour, even darker than the divisions made with ink on the scale on which the instruments were focussed. I used threads of 20 microns diameters, and they can be fixed on the diaphragm without much difficulty by means of a mixture of resin and mastic applied with a heated wire, and his mixture answers better than brittle shellac. It is obvious that the threads, when laid down in the diaphragm, are at once stretched, and remain in good condition, as they are not affected in any appreciable degtee by the influence of heat and atmospheric moisture.

The Ilague, June 18.

\section{Bullet-Proof Shields.}

In reply to a letter on bullet-proof shields, in the last number of NATURE, I wish to state that some preliminary experiments with spheres show that the energy of the shot is transmitted to the spheres nearly in line with the direction of the blow, to such a degree that great damage is done to the board to which the spheres are attached. This is not the case when rods are used. I hope shortly to give the details of my experiments on the suliject.

Oxford, June 16

FREDERICK J. SMITHI.
THE HORN EXPEDITION FOR THE SCIENTIFIC EXPLORATION OF CENTRAL AUSTRALIA.

I NFORMIATION has been received of the organization and desfatch from Adelaide of a new and wellequipped expedition for the scientific exploration of the Macdonnell Ranges which lie about eleven hundred miles to the northward of that capital and nearly in the centre of the Australian continent. The expense of this. expedition is borne by a wealthy and public-spirited colonist of South Australia, Mr. IVilliam Austin Horn, who thirty years ago carried out on his own account some explorations in the Gawler Ranges, and has sincetaken a very active part in the development of the mineral resources of the country, besides being a prominent member of the colonial legislature and of the Council of the University of Adelaide. Mr. Horn himself is the leader of the present Expedition, but has wisely associated with him some scientific gentlemen of great experience in Australian travel. Among them are Mr. Charles. Vinnecke, of the Trigonometrical Survey of South Australia, who in the performance of his duties has repeatedly traversed some of the most arid country of the continent, and has mapped out some thirty thousand square miles of its surface. WVith him also goes as niedical officer, Dr. E. C. Stirling, C.M.G., F.R.S., of theUniversity of Adelaide, the well-known discoverer, a few years since, of Notorycles, and Jatterly the investigator of the Diprotodon-deposits, the results of which so many are impatiently expecting, though now it is clear that for them they will have to await his return from this new undertaking, the charms of which he found it impossible to resist. Besides these there are of the party, Prof. Ralph Tate, also of the University of Adelaide, and President of the last meeting of the Australasian Association for the Advancement of Science, eminent as a palæontologist, and especially as a palæo: botanist, as well as Prof. Baldwin Spencer, whose name, from his connection with Owens College and Oxford, will be at once recognised by all; while there is also $\mathrm{Mr}$. J. Alexander IVatt, of the Geological Survey of New South Wales, to pay special attention to mineralogy and petrology. In the capacity of collecting naturalists, Mr. F. IV. Belt, of Adelaide, and Mr. G. A. Keartland, of Melbourne, complete the staff of the expedition, which will be accompanied by three camel-drivers, a cook, and two prospectors sent by the Gnvernment. The Expedition was to leave Adelaide on May 3 rd for Oodnadatta, and thence proceed along the telegraph line as far as Lilia Creek, where it will turn to the westward towards the Ayers Range and Goyder's Springs, after which it will make for the Palmer River, and then, deviating again to the westward towards Petermann Creek, will return to the upper valley of the Finke River, and then push on to Glen Helen at the foot of the Macdonnell Ranges. It will of course be understood that circumstances may cause this plan to be modified more or less extensively; but from the previous experience of those who have laid down the route to be taken it will probably be carried out pretty much as is intended, though some of the country to be traversed is absolutely unexplored, and much of it very imperfectly known. Wherever a prospect of doing work is found, a longer or shorter halt will be made, and as the Expedition is to be well furnished with camels-no fewer than twenty-three being taken with it - the difficulties that attend the needful supply of water will be reduced to a minimum, while it is said that owing to recent good rains in the latitudes to be passed through everything looks promising for a successful journey.

The importarce of this undertaking is not easily to be over-rated. Expeditions of one kind or another to the interior of the continent have been numerous, and

No. $12 S 6$, vOL. 50] 